\title{
008 \\ Species diversity and forage value of herbage in a neglected coconut land proposed for livestock integration
}

\author{
L Kumanayaka, T Seresinhe, M de S Liyanage and I Pathirana \\ Faculty of Agriculture, University of Ruhuna, Mapalana, Kamburupitiya, Sri Lanka.
}

\begin{abstract}
The proposed coconut land is situated in the southern province. belongs to the land suitability class $\$ 4$ which is moderately suitable for coconut. Therefore, managing coconut as monoculture is unprofitable and steps have been taken to optimize the land use through livestock integration. Therefore, objective of this study was to investigate the species diversity and forage value of understory vegetation in the coconut land before introducing cattle. Stratified quadrate sampling technique was adopted and 4 samples each from 6 paddocks (approx 0.4 ha) were randomly taken. Each stratum contained more than $80 \%$ of edible species while the non edible species found in all strata were common upland weeds. Axonopus affinus (carpet grass), Axonopus compressus (narrow carpet grass) and Desmodium trifolium were dominant prostate grass and legume species found in $0-5 \mathrm{~cm}$ strata above ground level. In addition to above species Fueraria phasioloides (Centro) was found to be dominant in $5-15 \mathrm{~cm}$ strata. Crysopogen ariculatus and Pueraria phasioloides were dominant in $15-25 \mathrm{~cm}$ strata while Seteria anceps (fox tail grass) found to be dominant above $25 \mathrm{~cm}$ height. The common non-edible species found in the lower two strata's were Urenalobota, Hemidesmats indicum and Ocimum tenuiflorum while Lantana camara and Ocimum tenuiflorum were dominant in upper two strata's. The dry matter (DM) and crude protein (CP) content of edible herbage increased from bottom to top layers ranged from $390 \mathrm{gkg}^{-1}$ to $480 \mathrm{gkg}^{-1}$ and $75 \mathrm{gkg}^{-1}$ to $100 \mathrm{gkg}^{-1}$ respectively.
\end{abstract}

The results of this study reveal that the species diversity and forage value are in an acceptable standard to initiate cattle grazing. However, crop and cattle management strategies are important in order to improve coconut and livestock performance.

\section{$\underline{009}$ \\ A study on palmyrah (Borasus flabellifer) utilization pattern and socio- economic status of dependent livelihood in Mannar district of Sri Lanka}

\author{
$S$ Arulmageswaran, I M N Chandrasiri and J V Culas \\ Extension and Training Centre, Department of Agrisulture, Peradeniya, Sri Lanka
}

Tha palmyrah palm (Borassus flcbellifer L.) is a multipurpose tree of great utility, occurs extens vely in Northern and Eastern part of S.i I c.?k . This tree engages human labour in the industries around it irrespective of gender or age. This survey was carried s!: to study utilization pat ${ }^{+} e r n$ of palmyrah tree and assess the sociccconomic parameters of ran-tomly selected 60 families registered in five cooperative societies of Mannar district.

This study revealed 1 hat $93 \%$ of males and $7 \%$ ol females entirely engaged $i_{1}$ this industry with th: average of 1.2 perso:s from each family. The average monthly family income of study population

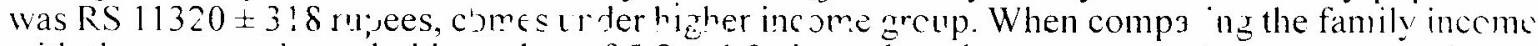
with the average household numt er of $5.8 \pm 1.3$ st o r i nadequacy to meet present expend ture. Further more, study showed that these families did not show much interest on children education and most cf youngsters leave school before sitting General Certificate of Education Ordinary Level examination. $58 \%$ of families were living in small $\mathrm{cr}$ medium size cottage made up of timber and palmyrah leaves as roofing material.

Tapping of matere tree was main source of income. One male tapped $14 \pm 2.7$ trees per day with the average of $8 \pm 1.2$ liter of toddy per tree. They did not produce sweet toddy (unfermented sip) because oi low demand. They normally market toddy (fermented sap) to their customers for drinking, co-operative society under palmyrah development boatd and for vinegar production. The price of toddy also varied from RS 6 to 20.00 rupees depending on quality. Apart from that, most of the tappers had to travel about $3 \mathrm{~km}$ out of co-operative boundary for tapping and selling their product. During off season and free time, they do timber carving, animal raring and palmyrah tuber production. Women did not actively engage in this industry except few workers in coir factory. Based on this 
study, it is concluded that this industry provides vast opportunity for further exploiting labour force in respect to production of beverage, sugar, alcohol, fibre, fuel wood, timber and row materials for handicrafts. As well as this study clearly stated that implementing innovative technologies with product diversification and opening new market channels are the necessary pre requisite of this industry in future.

\title{
010 \\ Effect of free range poultry system on land use efficiency and floral diversity in Rubber plantations
}

\author{
B M D C Balasooriya', V H L Rodrigo', S M M lqbal' and D V S de S Gamage², \\ ${ }^{1}$ Rubber Research Institute of Sri Lanka, ${ }^{2}$ Veterinary Research Institute, Sri Lanka
}

Plantation crops like rubber were traditionally grown in monocultures to avoid any risk on their productivity. However, with the smallholder farmers being involved in rubber cultivation, the idea of farming system evolved with the maximizing the overall land productivity and diversifying the income sources in order to meet the need of the resource poor. At present, rubber based intercropping systems with other economically beneficial crops are recommended and being practised to some extent particularly in smallholdings. However, no successful attempts were taken on livestock integration to the rubber system. With the understanding of practical limitations in incorporating ruminants to the system, the present study was commenced as a preliminary investigation to assess the effectiveness of free range poultry with respect to productivity and its effects on floral diversity under rubber. Based on the experience in coconut based poultry systems in Sri Lanka, a strain developed as a backcross of the hybrid between CPRS (Central Poultry Research Station) Brown and indigenous with indigenous, was used in this study expecting desired characteristics of both types. i.e., high level of egg production and adaptability to the environment. The trial began with 30 birds in a mature rubber clearing of the Rubber Research Institute of Sri Lanka. Information on egg production, the effect poultry on weed growth and its diversity were recorded together with visual observations on birds' behavior.

Average egg production was 8 eggs per bird per month. This value has dropped to 3 when the majority of birds were in moulting, However, in some months, it has gone up to 14. Some birds were killed by predators and even unsuccessful attacks affected the egg production. Birds showed poor brooding characters with that attempts taken to hatch eggs were failed. Poultry feeds had to be supplied ( $50 \mathrm{~g}$ layer ration per bird) to maintain the continuous egg production. Birds always used to feed on the area close human dwelling. Dominance of the floral species under rubber was changed with the incorporation of poultry. Although Adiantum latifolium was dominant throughout the study. Summed Dominance Ratio (SDR) of Paspalam conjugatum and Syngonium podophyllum declined with the poultry integration. Measures to be taken to improve the poultry system were also identified.

\section{1 \\ Rubber latex production in Hevea brasiliensis with high density planting \\ T U K Silva', V H L Rodrigo', S M C U P Subasinghe ${ }^{2}$ \\ 'Rubber Research Institute of Sri Lanka, \\ ¿Department of Forestry and Environmental Science, University of Sri Jayewardenepura, Sri Lanka.}

Despite short-term fluctuation of rubber prices, the demand of natural rubber has increased continuously with the increase in population and living standards of the human being. Nevertheless, urbanization results in the fast depletion of forests as well as the land area under rubber. Therefore, in order to meet the continuous demand on latex, the productivity of rubber plantations should be increased. While producing high yielding clones for improved yield per tree which is a long-term process in perennial crops, planting density could be adjusted to obtain high productivity in rubber plantations. The present level of planting density of rubber in Sri Lanka has been decided on the experiments conducted with the genotypes which are not in common use at the moment. Also, the optimum density should vary with different socio-economic conditions. Therefore, the present study was aimed to identify the suitable planting density for the recently developed and commonly used genotypes of

Proceedings of the International Forestry and Environment Symposium 2006 of the

Department of Forestry and Environmental Science. University of Sri Jayewardenepura, Sri Lanka 